\title{
Social and Institutional Trust in Times of Crisis: Greece, 2002-2011
}

\author{
Heikki Ervasti $^{1}$ (D) Antti Kouvo ${ }^{2} \cdot$ Takis Venetoklis $^{1}$
}

Accepted: 17 February 2018 / Published online: 14 March 2018

(C) The Author(s) 2018

\begin{abstract}
Focusing on 2002-2011, we analyse levels of trust in Greece and compare them with 17 other European countries. During this period, Greece endured a serious economic crisis. Signs of increasing mistrust in all societal institutions became evident and the nation witnessed extreme phenomena, such as violent demonstrations, the surfacing of radical political ideas, parties with nationalistic and racist characteristics, and noncompliance with rules, regulations, and taxes. However, little is known about generalised social trust, i.e. interpersonal trust between individuals, during the crisis. We analyse data from the European Social Survey Rounds 1, 2, 4, and 5 to test whether the crisis affected the levels of various forms of trust among Greeks. In addition to social trust, we distinguish between trust in political institutions (e.g. politicians and the national parliament) and impartial institutions (e.g. the police and legal system). The results reveal that the level of trust people show towards political and impartial institutions decreased substantially in Greece. Surprisingly, however, interpersonal social trust did not collapse; rather, it remained stable or even slightly increased concurrently with the notable decrease in political trust. This suggests that during an economic crisis, people do not deterministically lose their trust in other individuals; instead, in the Greek case they appear to lean on each other when both political and impartial institutions fail. Moreover, it is possible that shared experiences of nearly overwhelming adversities in Greece during the crisis increase a sense of togetherness among individuals, which in turn contributed to the robustness of social trust.
\end{abstract}

Heikki Ervasti

heikki.ervasti@utu.fi

Antti Kouvo

antti.kouvo@uef.fi

Takis Venetoklis

ta_vene@yahoo.com

1 Department of Social Research, University of Turku, Assistentinkatu 7, 20014 Turku, Finland

2 Department of Social Sciences, University of Eastern Finland, PO Box 1627, 70211 Kuopio, Finland 
Keywords Social trust $\cdot$ Institutional trust $\cdot$ Economic crisis $\cdot$ Greece

\section{Introduction}

The paper analyses different socio-economic conditions in 18 European countries during 2002-2011, in the middle of which a serious global economic crisis erupted. We focus on the individual-level effects of the crisis by investigating how the economic turmoil affected levels of trust towards central societal institutions, as well as towards other people. Our analysis focuses especially on Greece, as the country has endured the harshest economic recession during the studied period. We, thus, examine whether the crisis has negatively affected Greeks' levels of social and institutional trust, and compare these measurements with those of the other 17 countries in our dataset.

Trust forms the foundation of a well-functioning society. It may be defined as either institutional trust towards public institutions, or interpersonal social trust towards other people. Trust in institutions is an important component of democratic societies, as it is essential for the smooth operations of all interactions between governmental institutions and citizens. Likewise, generalised trust towards personally unknown fellow citizens is another fundamental asset of society and an important element of the social and political realm (Delhey and Newton 2003). In contrast, low or declining levels of trust are often associated with many distractions in society, such as lower levels of happiness, wellbeing, and health among individuals (Helliwell et al. 2014; Kawachi et al. 2007; Putnam 2000); possible reluctance to comply with legislation (Dalton 2004; Levi 1998; Marien and Hooghe 2011); and even higher potential for social unrest (Almond and Verba 1963).

It is logical to expect a severe economic crisis to violate trust. However, we emphasise the importance of distinguishing between institutional trust on the one hand, and social trust on the other. Earlier evidence (e.g. Miller and Listhaug 1999; Newton 2007; Polavieja 2013) shows that economic crises and the accompanying rise of unemployment and deteriorating living conditions, reduce people's institutional trust. This appears rational, especially in such cases as Greece, where several attempts to improve the economic situation have failed, bringing nothing but disappointment to the nation's citizens. In fact, some authors (e.g. Torcal 2014; Denters et al. 2007) argue that poor political performance and unresponsiveness of political institutions to citizens' demands during the crisis are even more important causes of the decreasing levels of trust than the economic crisis itself. Recent years, especially in Greece but also in Spain and Portugal, have witnessed such phenomena as violent demonstrations, the surfacing of extreme political ideas and parties and movements with nationalistic and racist characteristics, and noncompliance with rules, regulations, and taxes. With increasing numbers of people starting to care neither for the rules set by the government nor for the established social norms, the situation is indicative of declining levels of trust. Unsurprisingly, concurrent record low levels of political and institutional trust among their citizens are also being reported in these three countries (Exadaktylos and Zahariadis 2012; Roth et al. 2011; Torcal 2014, 2017).

However, much less is known about how, if at all, social trust between individuals was affected during the same period, and what could have been the driving force of any changes. Again, it would be very tempting to reason that increased unrest, even including violent outbursts within some demonstrations, is likely to stimulate suspicion of, rather than trust towards, other individuals. Nevertheless, in this paper, we show that unlike institutional trust, social trust towards other individuals was not necessarily damaged by the 
economic crisis. Using data from a representative time series survey in Greece and 17 other European countries during the crisis period, our analysis shows that, simultaneously with declining levels of institutional trust, social trust has remained stable or even slightly improved. We assert that there may be two reasons for this. First, it is possible that social trust persists because people seek support from their fellow citizens, as the welfare state and other formal government protections obviously fail. Second, persisting or even slightly increasing social trust may well be a product of accrued sentiments of togetherness, as the majority of the nation faces the extreme adversities of the economic crisis.

The rest of this paper is structured as follows. We start by describing the background and main characteristics of the economic crisis and its social consequences in Greece in more detail. As our main focus, the phenomena of social and institutional trust are then defined. Subsequently, we state our research questions and hypotheses more precisely, then describe our empirical data and methods, and present the results of our empirical analysis. Finally, in the concluding section, we discuss the theoretical and policy implications of our findings.

\section{The Greek Crisis}

In this section, we analyse how social and institutional trust developed in Greece during the 10-year period of 2002-2011. Especially during the latter years of the scrutinised period, Greece experienced an unprecedented economic crisis, social unrest and political instability. Briefly, the crisis derives from ineffective fiscal policies during the previous decade. As the political system was unable to apply measures reversing the trend, a neartotal collapse of the Greek economy ensued in the aftermath of the 2008 downturn in the international banking system. Public debt and the budget deficit skyrocketed; suddenly, the Greek government lost trust in the international bond markets, which resulted in rapidly increasing interest rates. This, in turn, compelled the Greek government to request financial assistance from other eurozone countries and the International Monetary Fund (IMF). In return, it was obliged to implement very strict fiscal consolidation policies. Consequently, the level of unemployment rose rapidly. Concurrently, wage reductions, social security cuts and increased levels of taxation were imposed. The collective result was a decline in purchasing power among the majority of the population (for an overview, see Arghyrou and Tsoukalas 2011).

Probably the single most important factor that influenced the Greek economy in the early 2000s was the establishment of the common European currency, the euro, in 2002. Like other smaller European countries, Greece adopted the euro to secure strategic alliances with stronger partners and to secure its geopolitical interests. The common currency was claimed to substantially reduce pricing and transaction costs, thus further boosting economic growth and prosperity (Christopherson et al. 2015). Nonetheless, eurozone membership deprived national governments of some tools they had previously used to stabilise their economies during economic downturns. The most notable loss was the ability to devalue one's national currency. Thus, periodic booms and busts in economic activity at national level did not converge at the supranational level (De Grauwe 2013).

From 2002 to 2008, several Central and Northern European countries experienced high current account surpluses. Germany in particular, which had since 1997 applied a policy of internal devaluation by freezing wages, enjoyed persistent surpluses and higher GDP growth than the eurozone averages (Simonazzi et al. 2013). Conversely, Greece and other 
countries in Southern Europe faced huge deficits, which were financed by credit sourced mostly from the eurozone's surplus economies. While external economic shocks were relatively weak, the deficits continued to be refinanced by rolling over sovereign debt in the bond markets and with relatively low interest rates.

In 2008, in the United States, a financial crisis erupted due to a previous overabundance of investments with mortgage-related securities as collateral. The crisis in the US, together with the exposure of the banking sector to sovereign debt, led to an increase in interest rates in the weak Southern European economies, which were suddenly unable to refinance their deficits. In these circumstances, first the Greek government, and then those of Spain, Portugal and Ireland, had no choice but request financial assistance from the other eurozone countries.

The prerequisites imposed by the lenders for such assistance were very harsh. Public sector expenditures were curtailed drastically, while increases in direct and indirect taxes were also imposed in the hope that the public deficit would be reduced and lower costs would make firms more competitive, thus reinvigorating the Greek economy. Unfortunately, the fiscal consolidation measures proved to be inefficient in turning around the economy. Contrary to what was envisioned, domestic demand was reduced, deposits in banks were withdrawn, many firms closed down, unemployment rose even higher, and political turmoil ensued. The effects of the austerity measures were felt mostly in the wellbeing of Greeks in general but especially among the nation's most vulnerable groups. (Karanikolos et al. 2013).

The Greek welfare state has traditionally been comparatively weak, whereas the role of the family has been central as a source of support for people in need (see Matsaganis 2012; Sotiropoulos and Bourikos 2014). Greek social security benefits, such as unemployment assistance, have been among the lowest in Europe, include strict eligibility criteria and cover a more limited duration than the corresponding benefit schemes in many other European countries. As the austerity measures were introduced, even those small benefits were significantly cut. Consequently, the Greek welfare state was even more poorly equipped to meet the increasing demands caused by the collapse of the economy. Along with its comparatively weak welfare state, Greece has traditionally been a low-trust society in terms of both institutional and interpersonal trust (Delhey and Dragolov 2013; Kouvo et al. 2012; Paraskevopoulos 2012).

When the welfare state fails, people usually turn to informal help and support from their families and relatives. However, the potential of the family to support its members also declined due to the crisis. For example, cuts in pensions reduce (grand) parents' ability to support their unemployed (grand) children.

Overall, from the perspective of wellbeing alone, some social policy analysts concluded that the austerity measures, in combination with the deregulatory and pro-market policy reforms pursued by Greek governments, culminated in an 'anti-social policy'. According to Papadopoulos and Roumpakis (2012: 204) instead of alleviating the crisis, this 'severely reduced socio-economic security, traumatised social cohesion and democratic governance, and sunk the Greek economy into the deepest and most prolonged recession in recent memory with detrimental effects for the state's finances and Greek society more generally'. Indeed, in addition to the increasing levels of unemployment and poverty, the number of homeless people also rose dramatically, and various types of social ills, including 
health-related problems, divorces, violent crime and even suicide mortality, increased notably (Ifanti et al. 2013; Kentikelenis et al. 2014; Rachiotis et al. 2015). ${ }^{1}$

\section{Social and Institutional Trust During An Economic Crisis}

As noted above, it seems highly rational to expect economic, political and social turmoil to damage individuals' trust towards both institutions and other individuals. In Greece, there were obvious signs of this. Demonstrations, violence, crime and disobedience can easily be interpreted as signs of declining trust. Nevertheless, to assess the effects of the crisis on trust, it is important to distinguish between different types of trust, namely social trust and institutional trust. From the classic writings of social research (e.g. Marx, Durkheim, Simmel and many others) to present day studies, a wide consensus about the great importance of both these types of trust has prevailed (see Zmerli and Newton 2013 for an overview). In this section, we first discuss these concepts and then formulate more explicit hypotheses about the possible effects of the economic crisis on these two types of trust.

As often noted, trust is an ambiguous scientific concept. Social trust is often used to refer to the horizontal aspect of trust, whereas institutional trust could be described as vertical trust in institutions (see Hardin 1999; Warren 1999). In addition, various forms of particular trust (or in-group trust), i.e. trust within close personal networks, family and closest friends, are often identified (e.g. Hardin 2000; Uslaner 2008). However, this form of trust is not included in this analysis. Our conceptualization of trust considers the wider society and our focus is on the 'bridging', rather than the 'bonding', type of social capital (Putnam 2000: 23).

Social trust, also known as interpersonal or generalised trust, expresses to what extent people have faith in other people, especially in those they do not personally know. At a general level, social trust can be defined as the 'belief that others will not, at worst, knowingly or willingly do you harm, and will, at best, act in your interests' (Zmerli et al. 2007: 38). In other words, generalised social trust is the conviction that most people can be trusted even if you do not know them personally or even if they are not like you socially (Uslaner 2000: 573). Thus, rather than plain gullibility, the idea of social trust is based on the thought that trusting others is justified (Yamagishi 2001).

Institutional trust, conversely, focuses on actors and institutions, such as politicians, officials and organisations. Undoubtedly, as Warren (1999: 3-4) notes, modern, complicated political systems greatly rely on citizens' trust in governmental organisation and bodies. However, trust in institutions may vary notably between institutions, i.e. institutional trust is multidimensional (e.g. Rothstein and Stolle 2003: 193-195). In this analysis, we focus on two types of institutions by distinguishing between trust in impartial institutions, such as the police and the legal system, and political institutions, such as the national parliament and politicians.

Although much is known about trust, several issues, especially about the origins and the possible causal order between different forms of trust, still remain rather vague. An apparently widely shared view is that the emergence of interpersonal social trust requires societal and political institutions to provide a fair and efficient environment in which trusting

\footnotetext{
1 The crisis also sparkled drastic political changes in Greek society. Our data, however, is from the period before the elections that brought the rise of previously marginal political parties from polar ends of the political spectrum.
} 
is rewarded and not exploited (Brehm and Rahn 1997; Knack and Keefer 1997; Rothstein and Stolle 2003). Therefore, the source of social trust could be found in the design of public institutions and governing policies (Hooghe and Stolle 2003: 3). The debate over this topic is often entangled with discussion on whether the welfare state may 'make' or 'break' social trust (see Kumlin and Rothstein 2005). Some have even argued that excessive state intervention is detrimental to the creation of social trust, because social expenditures and generous social programs 'crowd out' informal social networks and, thus, reduce citizens' ability to benefit from face-to-face 'social capital' (Fukuyama 2001: 18). However, more recent studies do not seem to support this hypothesis (Kääriäinen and Lehtonen 2006; Kouvo et al. 2012; Kumlin and Rothstein 2005; Rothstein and Stolle 2003; van Oorschot and Arts 2005). The levels of all types of trust tend to be highest in the most developed welfare states equipped with generous and universal social policies, whereas in the welfare states characteristically based on residual social policies, the levels of trust remain clearly lower. Though these studies suggest that the universalistic type of welfare state has generated social trust, very few studies to date have analysed whether the positive association between the welfare state and social trust applies to a situation in which state institutions are deteriorating and social policies are being curtailed.

To further complicate the situation, in addition to state institutions, many other factors also seem to correlate strongly with the level of general social trust, such as equal income distribution, protestant tradition, the nation's wealth and ethnic homogeneity (e.g. Brehm and Rahn 1997; Delhey and Newton 2003, 2005). Many of these mechanisms have been produced through a long historical development, and there is no certainty which are the causes and which the effects (cf. Rothstein 2008).

Despite the prevailing lack of a unanimous view on the causal order between the various forms of trust and the other associated factors, matters are perhaps clearer regarding the effects of economic crises. It seems plausible to expect such crises to negatively impact institutional trust, i.e. towards the police and the legal system or the country's parliament and politicians. Intuitively, this appears rational. In good times, people trust political institutions that are seemingly able to generate economic growth and jobs, as well as to improve social security and services. Similarly, a low or even negative growth rate, unemployment and cuts in public services and the welfare state are likely to stimulate distrust among people. For example, Roth (2009; see also Braun and Tausendpfund 2014) shows that trust in the central European institutions, such as the European Commission, European Parliament and, especially, European Central Bank, fell to historically low levels among EU-citizens soon after the onset of the financial crisis of 2008. This happened especially in the wealthy European countries (Kuhn and Stoeckel 2014). Soon after the crisis erupted in 2008, trust in national political institutions also started to decline, despite an initial short-term increase (Roth 2009). The decline was most pronounced in Greece, Spain, Ireland, and Portugal: four periphery countries of Europe hit hardest by the international financial turmoil (Roth et al. 2011). ${ }^{2}$

\footnotetext{
${ }^{2}$ Some accounts have questioned the perceived positive association between economic success and some forms of trust. For example, van der Meer (2010) finds no correlation between political trust and economic performance on the macro level although citizens' own levels of household income did correlate with trust in parliament. van der Meer (ibid: 531) concludes that political trust "does not depend on actual (objective) economic performance, but at best on citizens' individual income levels or on their subjective evaluation of the economy". According to van der Meer (2017: 280) "macroeconomic performance does not have a consistent impact on political trust in cross-national studies, but is shown to be an important determinant in within -country, longitudinal studies".
} 
From a wider perspective, it is plausible to assume that an increasing proportion of the Greek public perceive their national political process to be defective, contributing, in turn, to the decline in trust in political institutions especially, but also, perhaps, in impartial institutions. According to Norris (2011), in most parts of the world, perceived democratic performance fails to meet public expectations, a gap that is actually becoming wider, especially in the most developed democracies. While the importance of citizens' evaluations of the political domain and democracy has been stressed by many authors (Alesina and Wacziarg 2000; Torcal 2014; van der Meer 2010, 2017), a democracy deficit may be expected to be especially pronounced in Greece, a country with obviously declining quality of governance, lack of accountability and political transparency, and a notable corruption problem (see Jones et al. 2008: Chapter 2; Paraskevopoulos 2012).

Earlier research on the association between financial crises and social trust is more limited. Again, however, it is intuitive to expect negative effects. Simply the fact that individual wellbeing is positively correlated with social trust suggests that, as economic crises decrease wellbeing, this also translates into declining social trust, whatever the causal relation. There is also evidence suggesting that social trust is affected by one's own negative experiences and, therefore, it declines during a crisis (van der Cruijsen et al. 2016). However, some scepticism regarding this finding can also be found in the literature. For example, Uslaner (2010) suggests that whereas trust in public institutions may change rapidly during a crisis, social trust seems to be more stable, though not immune to long-term malfunctioning of public institutions. Even more interestingly, Growiec et al. (2012) show that in Iceland-also in conditions of an extreme economic crisis- the level of social trust actually increased. Anderson (2015) notes that, in the post-socialist transition countries, social trust increased during the economic crisis, having earlier decreased during the transition period. Moreover, when coping with a crisis, the importance of trust is acknowledged in research. Helliwell et al. (2014) found that communities and nations with higher levels of social trust respond to sudden crises more efficiently.

Thus, while there are evidently obvious reasons to expect a decrease in institutional trust during economic crises, any effects on social trust are not as evident. It is possible that the development of the two types of trust varies between different segments of the population. There is evidence that the levels of trust fluctuate according to social stratification hierarchies, age, health, gender and such personal characteristics as sociability, optimism and other psychological personality traits. For example, Alesina and la Ferrara (2000) find that a recent history of traumatic experiences (of all types) correlates negatively with trust. In the Greek case, therefore, it seems plausible to expect that people who have experienced the severest economic misfortune on a personal level, as well as people with health problems, would have lost their trust in both institutions and other people. Regarding the effects of education and income, earlier findings suggest a positive association with trust (Alesina and la Ferrara 2000; Helliwell and Putnam 1999; Knack and Keefer 1997). Similarly, the effect of unemployment on trust may be expected to be negative (van Oorschot and Arts 2005). Concerning age and gender, earlier findings have shown less consistent relationships. Most analyses have found a positive impact of age on trust, but there also is evidence that the impact may be non-linear; on gender, there is evidence that women are less trusting than men (Alesina and la Ferrara 2000). Concerning different personal characteristics, our sample includes only measures of sociability; therefore, regrettably, this does not allow us to test the effects of many psychologically interesting personality traits. The effect of sociability can be expected to be positive on all types of trust. 


\section{Research Questions, Data and Methods}

To reiterate, our goal is to discover how the financial crisis and accompanying social deterioration affected the levels of institutional and social trust in Greece. It appears rational to expect that the severe social consequences of the economic crisis have negatively affected the levels of trust people show towards society's central institutions, and may also have violated people's trust in one other. More specifically, our research question can be formulated as follows:

1. How has the Eurozone crisis affected social and institutional trust in Greece in comparison with other European societies?

2. Which individual and demographic background factors account for the variations in trust?

We use data from the European Social Survey (ESS) Rounds 1, 2, 4 and 5, which cover the period of 2002-2010/2011 (European Social Survey 2002, 2004, 2008, 2010). In addition to Greece, we also use data from 17 other European countries (Belgium, Switzerland, The Czech Republic, Germany, Denmark, Spain, Finland, France, United Kingdom, Hungary, Ireland, Netherlands, Norway, Poland, Portugal, Sweden, and Slovenia as a reference point. These countries were selected due to data availability: only these countries participated, together with Greece, in all the aforementioned rounds of the ESS. Our sample comprises 129,007 observations of which 9204 persons are inhabitants of Greece. Though, in most countries, Round 5 of the ESS was conducted in 2010, the fieldwork in Greece was conducted between early May and July $2011 .^{3}$

The data contains measures on both social and institutional trust. To capture social trust, the survey uses a slightly rephrased version of the widely used Trust in People scale first introduced in the late 1960s (see Wrightsman 1991: 406). The exact wordings of these items in the surveys are: (1) 'Generally speaking, would you say that most people can be trusted, or that you can't be too careful?'; (2) 'Do you think that most people would try to take advantage of you if they got the chance, or would they try to be fair?'; and (3) 'Would you say that most of the time people try to be helpful or that they are mostly looking out for themselves?'. The answer scale options for all of these questions ranged from 0 to 10 where 0 refers to very low and 10 to a very high levels of trust. As our dependent variable depicting social trust, we use the average of the replies to these three questions.

To account for institutional trust, we use two measurements: one on trust in political institutions, such as the national parliament and politicians, and the other on confidence in impartial institutions, such as the legal system and the police. The exact wordings of these items are: 'Please tell me on a scale of 0-10 how much you personally trust each of the institutions I read out. 0 means you do not trust an institution at all, and 10 means you have complete trust ... (1) country's parliament, (2) politicians, (3) country's legal system, and (4) the police'. Here, again, we use the average of the replies to these two sets of questions to depict our two other dependent variables: trust in political institutions and trust in legal institutions, respectively.

As the independent variables, we use gender, age and age squared, educational attainment, subjective general health, household economic situation, respondent's sociability,

\footnotetext{
${ }^{3}$ More detailed information about the ESS is available at europeansocialsurvey.org.
} 
occupational class and labour market status, i.e. whether the respondent is employed, unemployed or outside the labour force. As explained above, prior research has shown that both social and institutional trust are associated with all these variables, so controlling for them is necessary. Age is measured in years as a continuous variable, and is restricted to respondents between 15 and 102 years old. Moreover, as earlier studies suggest that the effect of age is non-linear, we also include age squared in our models to capture possible curvilinear effects. Similarly, education level is measured in years that the respondent has spent in education. Subjective health is measured via binary categories (Good health $=1$; Fair health or worse $=0$ ). The household's economic situation is captured through binary self-reporting categories (a good economic situation or coping $=1$; having difficulties $=0$ ). Sociability is based on respondents' report of how often they meet their friends. Again, this variable comprises binary categories (more than once a month $=1$; less often $=0$ ). Occupational class is based on European Socio-economic Classification (ESeC, see Rose et al. 2010). However, since, in our preliminary analyses, we found statistically significant differences only between the 'highest salariat' (i.e. large employers, higher grade professionals, administrative and managerial occupations) versus all other classes, this variable was aggregated into just these two categories. Labour market status is a variable indicating whether the respondent was employed, unemployed or outside the labour force at the time of the interview.

In addition, to socio-economic variables described above, we added satisfaction with democracy to the models as a proxy for public institutions' perceived quality. We are, thereby, able to analyse whether citizens' evaluations of the functioning of the democratic system affect the various types of trust. Including this specific variable in the models may be criticised for its proximity to the operationalisation of political trust, i.e. the dependent variable. However, we also ran models without this specific variable, and the effects of the other independent variables remain practically the same. Detailed information of all the variables is shown in "Appendix 1", Table 2.

\section{Results}

In our empirical analysis, we examine Greece's levels of trust during the study period and compare them against the respective levels of the other 17 countries in our data set. We apply two estimation methods (models) for each of the three types of trust we described earlier: i.e. the dependent variables Social Trust, Trust in Political Institutions, and Trust in Impartial Institutions). The results are shown in Table 1. The first estimation method is a fixed-effects ordinary least squares (OLS) regression, with main and interaction effects of Country and Round dummies (Models 1, 3, and 5). We, thus, create a separate intercept for each dependent variable used. In addition, on the right-hand-side of each of the models, we add the individual-level predictors listed earlier: i.e. occupational class, labour status, education level, age and age-squared, gender, subjective health, household economic situation, sociability, and satisfaction with democracy.

To test for robustness, we also analyse the data with another regression method. Through individual-level observations per country and per round, we estimate the effects of the predictors on the dependent variables using multilevel analysis (Schmidt-Catran and Fairbrother, 2016). We have data that is nested and hierarchically structured, with individual-level responses compiled per round (year) and per country which justifies the use 


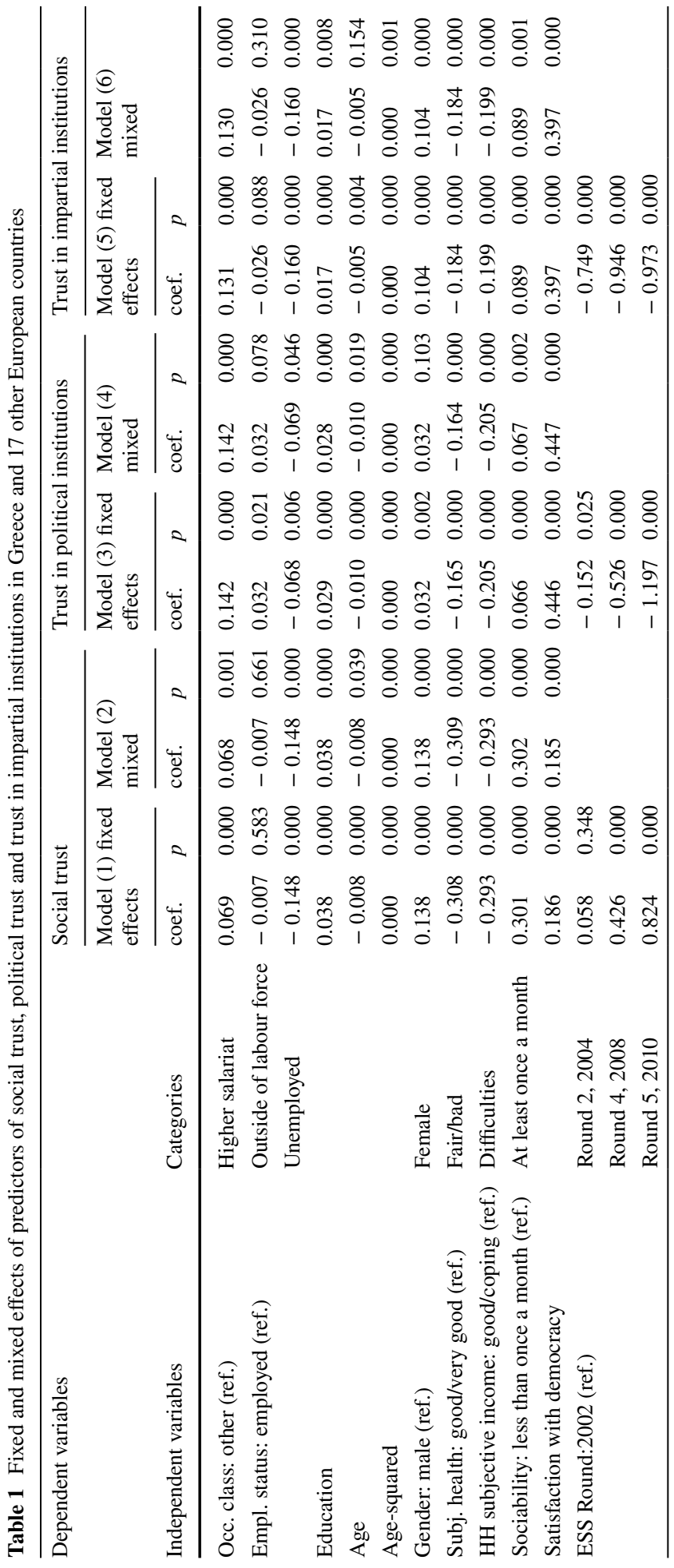




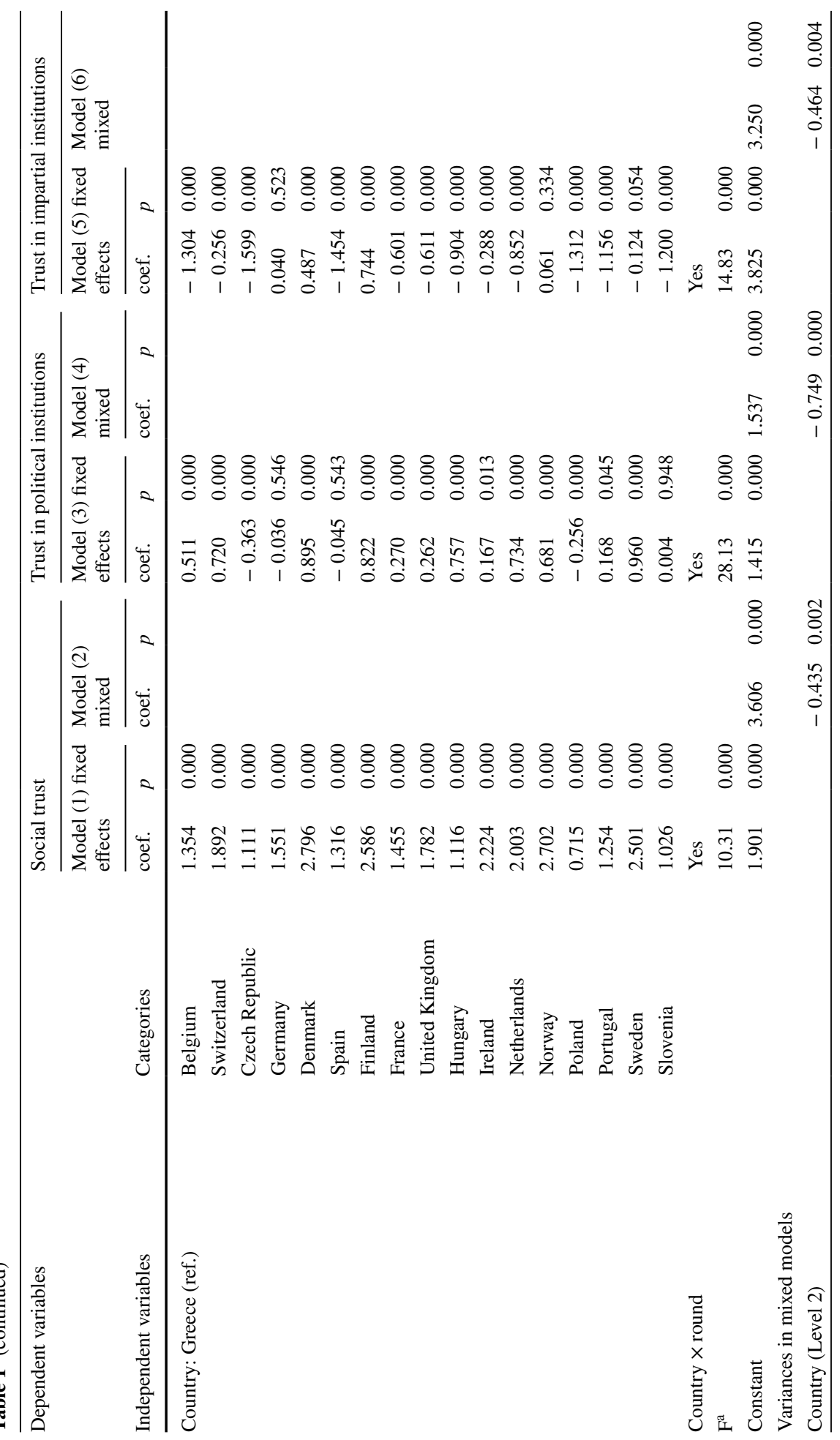




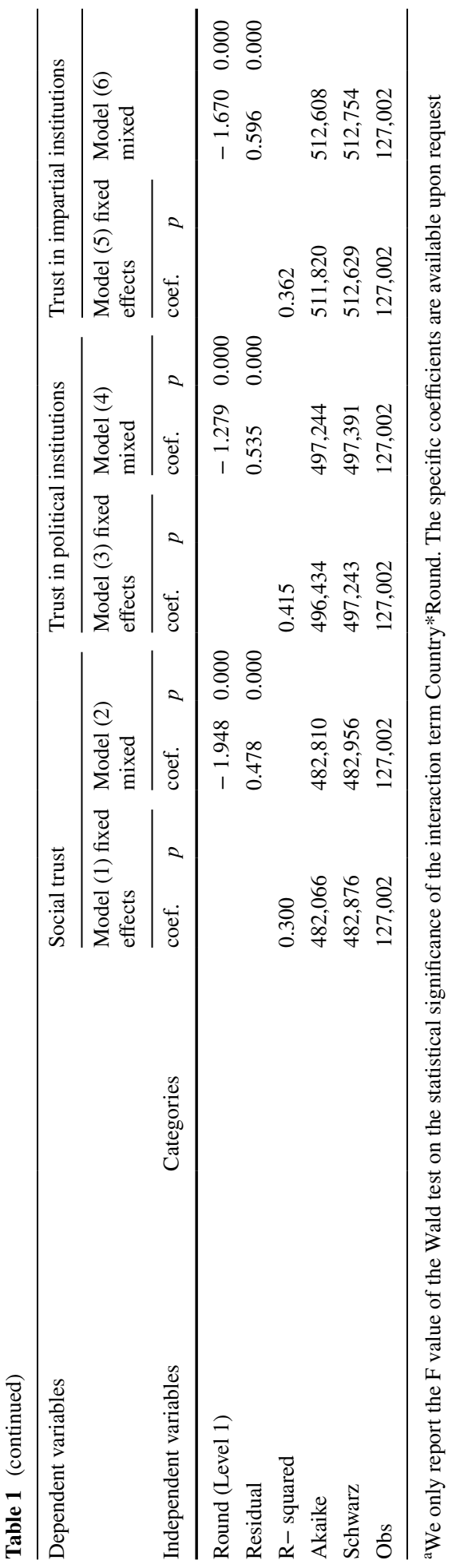


of multi-level approach. With four rounds of ESS data, this multilevel analysis takes into account the time series feature of the responses. ${ }^{4}$

The specifications for the mixed effects models are similar to those of the fixed effects OLS. Social Trust, Trust in Political Institutions, and Trust in Impartial Institutions are the dependent variables. In the fixed part of the models, we include the same individual level predictors as previously. In the random part, we define the Country dummy of the respondent as the third-level grouping variable and the Round (year) of the survey as the secondlevel grouping variable. The first level comprises the individual observations. Basically, we build a three-level random intercept model (Models 2, 4, and 6), in which the three types of trust are controlled by the variables found in the fixed part, but have different intercepts (mean values) within each country and for each round year in the data. In these models, the relationships between Trust (Social, Political, and Impartial) and all the predictors in the fixed part have the same slope.

Almost all individual-level independent variables have statistically significant coefficients in both the fixed effects and mixed models, irrespective of the type of trust examined. The values fluctuate somewhat, but their signs remain similar in all continuous predictors and all groups of the categorical variables. Respondents classified in the higher salariat class have, on average, higher trust than other respondents. Similarly, those employed have higher trust than those who are not. The more educated one is, the more trust one has towards not only other people but the political and legal system of one's country. Age is associated with trust in a non-linear fashion: as one grows older, trust diminishes, but then grows again after a certain age. However, the curvilinear effect is rather small. Female respondents generally report having more trust compared to their male counterparts. As expected, those with poor health are more suspicious than others towards other people, the political system, and even impartial institutions. The same is observed for those with financial difficulties versus those who are economically secure. Finally, our initial hypothesis that a person's evaluation of a country's democratic system might be strongly associated with all three types of trust is validated: the relevant coefficients in all six estimations are positive and statistically significant suggesting that, in addition to economic success, the levels of the various forms of trust depend on political performance of a country.

As discussed earlier, in the fixed effects OLS models, we also include the main and interaction effects of Country and Round. The interaction terms in Models 1, 3, and 5 are statistically significant, which indicates considerable significant differences in trust between countries and within each round. This is also confirmed in the mixed Models (2, 4 , and 6), in which the variances of the three dependent variables between countries and within rounds are statistically significant.

In the fixed effects OLS estimations, we chose Greece as the reference category for the Country variable. For the main effect estimations in which the dependent variable is Trust in Political Institutions or Trust in Impartial Institutions (Models 3 and 5), in comparison with Greece, the coefficients of the other 17 countries have different signs and are not always statistically significant. However, the coefficients become more consistent when the dependent variable is Social Trust (Model 1): all the main effects country coefficients have a positive sign and are statistically significant.

To more closely examine these relationships, we estimate, for each of the fixed effects OLS models, the marginal effects of the Country and Round interaction.

\footnotetext{
4 The command mixed (Stata, v.14.2) was used for the analysis, generating a fixed and a random part (for more detail, see Rabe-Hesketh and Skrondal 2012).
} 
Fig. 1 Predictive margins for social trust: Greece versus 17 European countries
-1 EU17

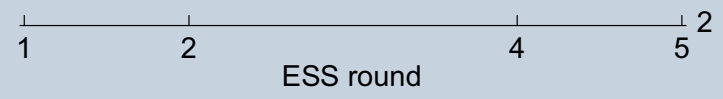

Fig. 2 Predictive margins for political trust: Greece versus 17 European countries

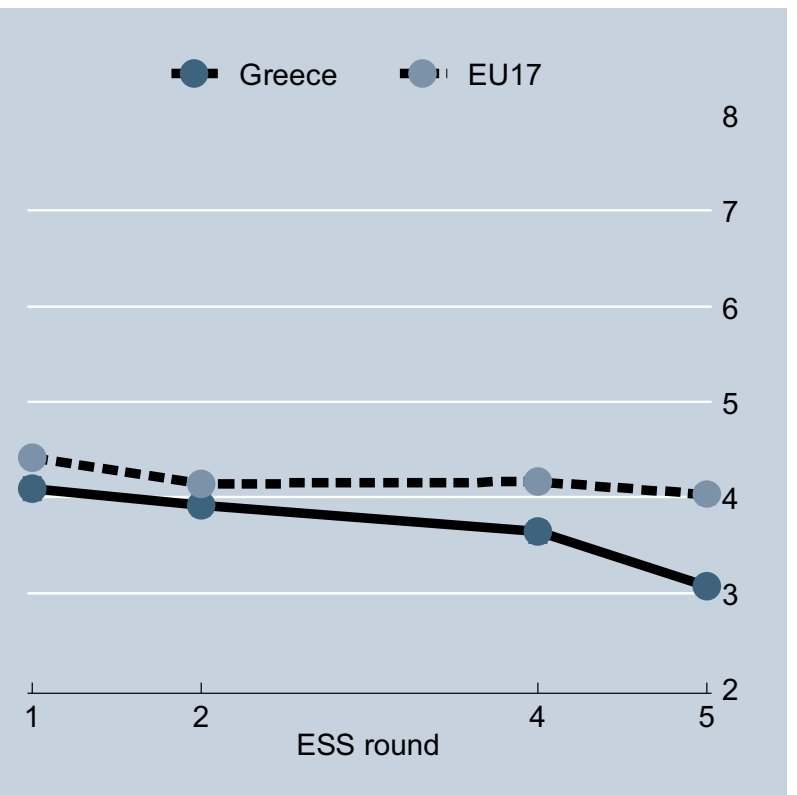


Fig. 3 Predictive margins for trust in impartial institutions: Greece versus 17 European countries

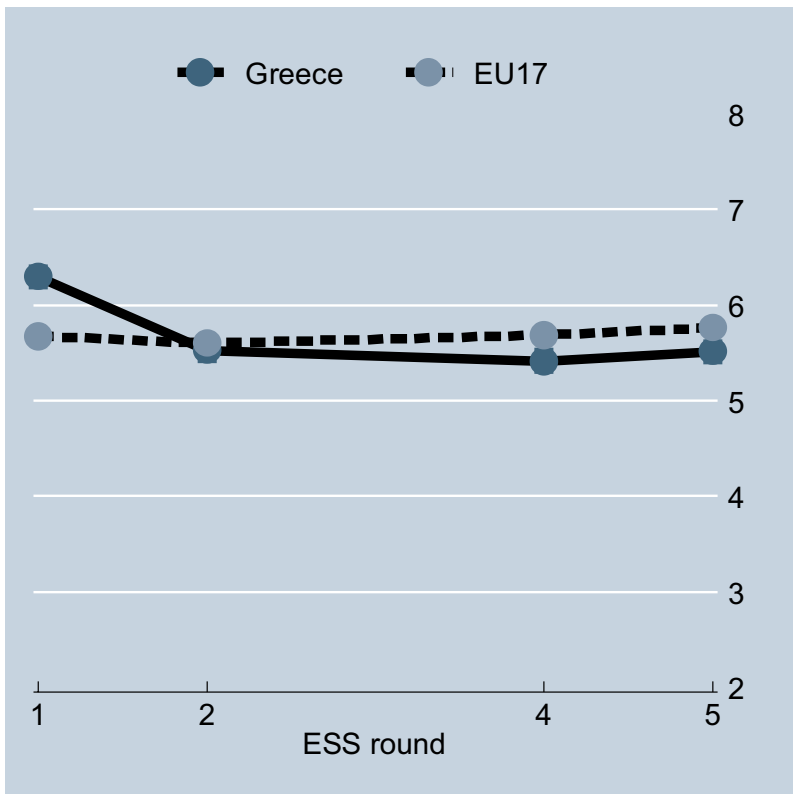

Graphical representations of these effects are shown in Figs. 1, 2 and 3 for Models 1, 3, and 5 , respectively. ${ }^{5}$

Greece reports the lowest social trust among the 18 European countries in each ESS round. However, after the crisis erupted, social trust rose considerably faster in Greece than in the other countries. The margin plot in Fig. 1 shows this clearly. In Greece, political trust was slightly lower than in the other countries already before the crisis. As the crisis developed it declined even more quickly (Fig. 2). Trust in impartial institutions, on the other hand, shows a somewhat different course (Fig. 3). Several years prior to the crisis Greece reported higher trust in impartial institutions than the rest of the countries. It then dropped to similar levels as the rest in 2004, and thereafter followed the same pattern as the other 17 countries, albeit at slightly lower levels.

The aforementioned comparisons plotted trust levels in Greece against those in all the other 17 European countries together. To test these differences in more detail, we aggregated the 18 countries into a five-categories variable: Greece, Scandinavian countries (Finland, Sweden, and Norway), countries severely hit by the recession (Spain, Portugal, and Ireland), Eastern European countries (Czech Republic, Hungary, Poland, and Slovenia) and the rest (Belgium, Switzerland, Germany, France, United Kingdom, and the Netherlands). We then estimated the marginal effects of this country variable by plotting its interaction with the survey round. The plots are depicted in "Appendix 2", Figs. 4, 5 and 6. Greece is still the only country that shows increases in Social Trust: the respective levels in the other country groupings remain almost flat throughout the investigated period, including the grouping of the other countries severely hit by the recession (Spain, Portugal, and Ireland). For Trust in Impartial Institutions, we note that all the groups show a slight increase

\footnotetext{
5 The plots were generated by estimating the marginal effects of Models 1, 3, and 5 where the country variable is binary $(0=$ Greece, $1=$ all other 17 European countries $)$. In those models, the other coefficients do not change considerably.
} 
whereas Greece shows a downward trend. Finally, Political Trust diminishes in Greece as well as in the other countries severely hit by the recession. However, the reduction is larger in Greece, especially between rounds 4 and 5.

\section{Conclusions}

In this paper, we examined what kinds of repercussions a severe economic crisis and the accompanying social disarray might have on the levels of trust in society. Using Greece as our empirical case, we distinguished between interpersonal social trust, political trust and trust in impartial institutions. The results showed that whereas Greeks lost their trust in both political and impartial institutions, their levels of social trust even slightly improved. This main finding did not change after controlling for several individual-level background variables. Consistently with prior findings, our results suggest not only that institutional and social trust are theoretically distinct components of trust but also that social changessuch as those caused by the Greek economic turmoil-may be reflected differently in these two forms of trust. Although trust in institutions may diminish, people do not seem to lose their trust in one another. This finding, although unexpected, also receives some support from earlier studies.

The decline in political trust is unsurprising. Especially during economically hard times, and whenever politicians fail, political trust declines. In Greece, people have been repeatedly disappointed with the attempts of politicians of various persuasions, to implement policies guiding the nation out of the crisis. Simultaneously with compliance packages and austerity measures, people have experienced increasing levels of unemployment, homelessness, poverty, worsening social security and health care. In other words, they have witnessed a reduction in the measures previously designed to tackle increasing social problems. Thus, it is not surprising that, in such an environment, people have lost their faith in not only political but also impartial institutions. Probably, the declining quality of government, lack of accountability and widely spread corruption have also contributed to the decreasing levels of trust in institutions. The very same phenomenon has been reported in the other two Southern European countries facing economic crises: Spain and Portugal (e.g. Torcal 2017).

Our analysis also shows that, contrary to widespread expectations, the economic crisis and increased distrust in the political domain did not tear apart the nation's social fabric in Greece. Our findings suggest that most people may even have started to lean on each other more than before. We suggest two reasons for this. First, as the welfare state and other government institutions have increasingly failed to fulfil their role, Greeks have been seeking more support from each other. Second, and simultaneously, it is also possible that shared experience of nearly overwhelming adversities may increase togetherness among Greeks.

The focus of this paper is in Greece, the country that was hit hardest by the economic crisis. In other words, Greece is the country where one could expect to find the most dramatic fall of all forms of trust. This is true considering political trust. A slight decrease of trust in impartial institutions can also be observed, although it started already before the crisis. However, social trust was not negatively affected by the crisis. Actually, our results indicate slightly increasing levels of social trust in Greece. Even as the country has had the lowest levels of social trust throughout our research period, it also enjoyed the highest percentage increase of all countries in our sample, although it was hit hardest by the economic crisis. As a conclusion, we argue that economic crises do not necessarily and deterministically destroy the social fabric of a society. Nevertheless, although Greece is 
the special focus of our analysis, this conclusion should be compared with the other crisisridden countries, especially Spain, Portugal and Ireland. Two of these, Spain and Portugal show a similar pattern as Greece (see "Appendix 2", Table 3). During our research period there was a slight increase of social trust in Spain, too. In the beginning, there was a slight decrease in social trust, but towards the end and despite the crisis, the levels of social trust clearly increased. In Portugal there was a negative trend in the levels of social trust before the crisis, which turned positive when the crisis erupted. Ireland is an exception. There, the economic crisis was accompanied by a decrease of all the three forms of trust. However, the decline of social trust, although clear, can hardly be interpreted as catastrophic. Even with the exception of Ireland, we can see that a slightly positive rather than a negative growth in social trust took place in three of the four crisis-ridden countries. Of course, the exceptional pattern of Ireland requires further investigation in the future.

To a certain degree, one might claim that our results support the crowding-out hypothesis, according to which government institutions disturb informal social networks and, thus, reduce citizens' ability to form and benefit from personal contacts with other individuals (Fukuyama 2001). However, we do not make this assertion. Our results do not indicate that the slight increase in social trust is caused by the weakening government institutions that otherwise suffocate the social fabric. Instead, especially in the Greek case, we think it is more plausible that the increase in social trust may be considered part of a coping strategy of people faced with declining levels of wellbeing.

A limitation of the study is the relatively short period it examines. As discussed in the method section, due to the unavailability of the ESS data, we were only able to analyse information for Greece up to 2011. Since then, Greece has not participated in the ESS, which is regrettable because extremely interesting data from these dramatic years has not been collected. A wider time coverage would also allow us to study the individual- and country-level mechanisms prevailing between financial crises and trust in public institutions. In particular, the political changes that have unfolded in Greek society since our data was gathered would be worth studying in greater detail. Today, the financial, social and political turmoil in the country is, however, in its ninth year. The probability for a mediumterm recovery has perhaps increased, but the promises of improvement in the quality of life for millions of Greeks have yet to materialise. Rather, a rising cleavage between the current leftist-rightist government coalition and the previous social democrats and conservatives may be observed, together with persisting social disarray. What happens to the levels of different forms of trust among Greeks remains to be seen when new data, hopefully, becomes available again. Nonetheless, our analysis indicates that, despite the extremely low levels of institutional trust, there is no categorical reason to expect a deterministic drop in the levels of social trust in the future.

Acknowledgements Funding was provided by Academy of Finland, Kulttuurin ja Yhteiskunnan Tutkimuksen Toimikunta (Grant No. 293200).

Open Access This article is distributed under the terms of the Creative Commons Attribution 4.0 International License (http://creativecommons.org/licenses/by/4.0/), which permits unrestricted use, distribution, and reproduction in any medium, provided you give appropriate credit to the original author(s) and the source, provide a link to the Creative Commons license, and indicate if changes were made.

\section{Appendix 1}

Tables 2 and 3. 


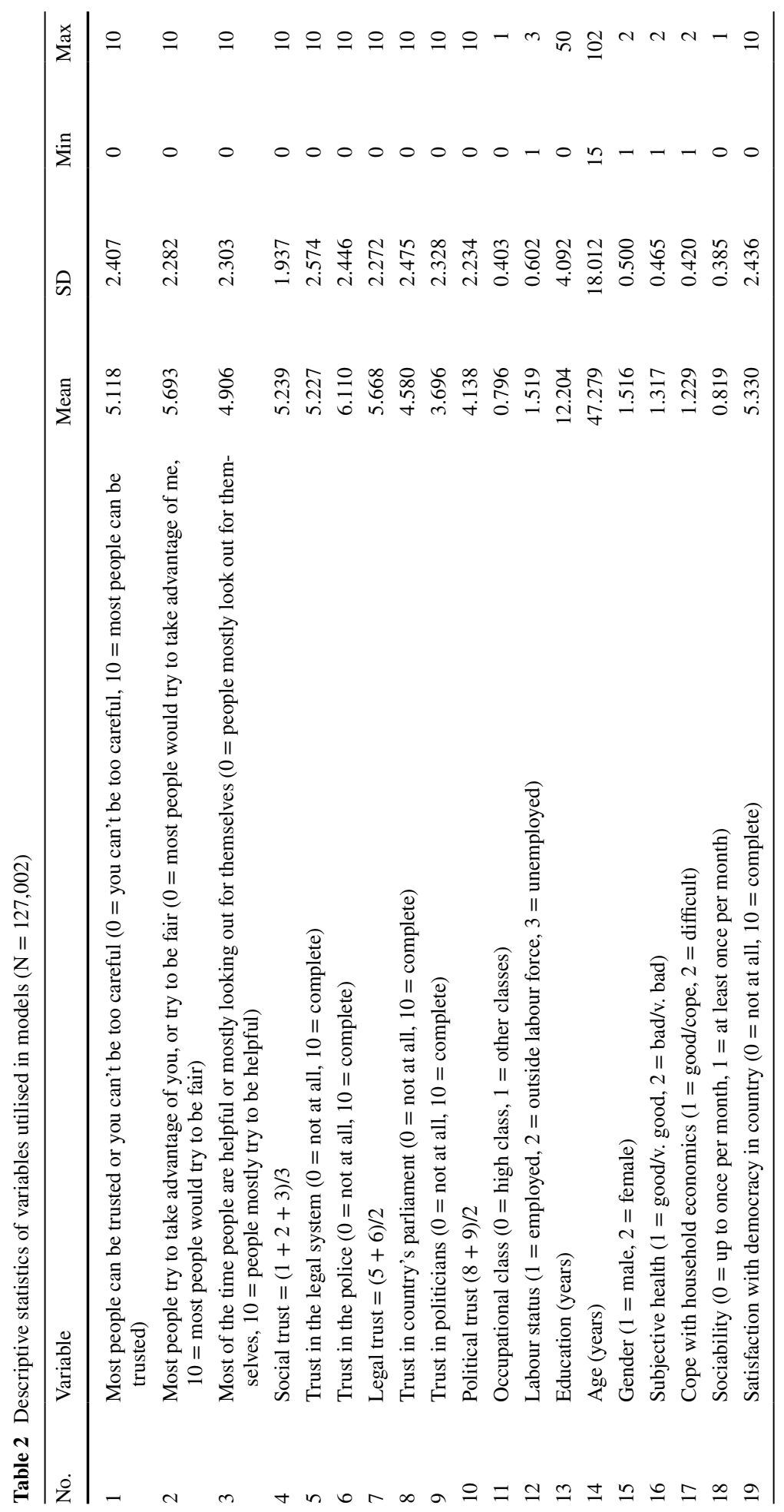


Table 3 Social trust, political trust and trust in impartial institutions in Spain, Greece, Ireland and Portugal, 2002-2010/2011. Marginal effects

\begin{tabular}{|c|c|c|c|c|c|c|c|}
\hline \multirow[t]{2}{*}{ Country } & \multicolumn{4}{|c|}{ Round and year } & \multicolumn{3}{|l|}{$\%$ diff from } \\
\hline & R1 2002 & R2 2004 & R4 2008 & R5 2010/11 & $\mathrm{R} 1-\mathrm{R} 2(\%)$ & $\mathrm{R} 2-\mathrm{R} 4(\%)$ & R4-R5 (\%) \\
\hline \multicolumn{8}{|c|}{ Trust in political institutions } \\
\hline Spain & 4.006 & 4.104 & 4.015 & 3.638 & 2.45 & -2.17 & -9.39 \\
\hline Greece & 4.049 & 3.895 & 3.523 & 2.852 & -3.80 & -9.55 & -19.05 \\
\hline Ireland & 4.216 & 4.118 & 3.843 & 3.586 & -2.32 & -6.68 & -6.69 \\
\hline Portugal & 4.217 & 3.968 & 3.730 & 3.481 & -5.90 & -6.00 & -6.68 \\
\hline \multicolumn{8}{|c|}{ Trust in impartial institutions } \\
\hline Spain & 4.764 & 5.046 & 5.000 & 5.434 & 5.92 & -0.91 & 8.68 \\
\hline Greece & 6.218 & 5.467 & 5.272 & 5.245 & -12.08 & -3.57 & -0.51 \\
\hline Ireland & 5.930 & 5.656 & 6.104 & 5.954 & -4.62 & 7.92 & -2.46 \\
\hline Portugal & 5.063 & 5.365 & 5.192 & 5.084 & 5.96 & -3.22 & -2.08 \\
\hline \multicolumn{8}{|c|}{ Social trust } \\
\hline Spain & 4.869 & 4.690 & 4.883 & 5.110 & -3.68 & 4.12 & 4.65 \\
\hline Greece & 3.553 & 3.609 & 3.979 & 4.376 & 1.58 & 10.25 & 9.98 \\
\hline Ireland & 5.776 & 5.903 & 5.967 & 5.641 & 2.20 & 1.08 & -5.46 \\
\hline Portugal & 4.807 & 4.828 & 4.641 & 4.728 & 0.44 & -3.87 & 1.87 \\
\hline
\end{tabular}

\section{Appendix 2}

Figures 4, 5 and 6. 


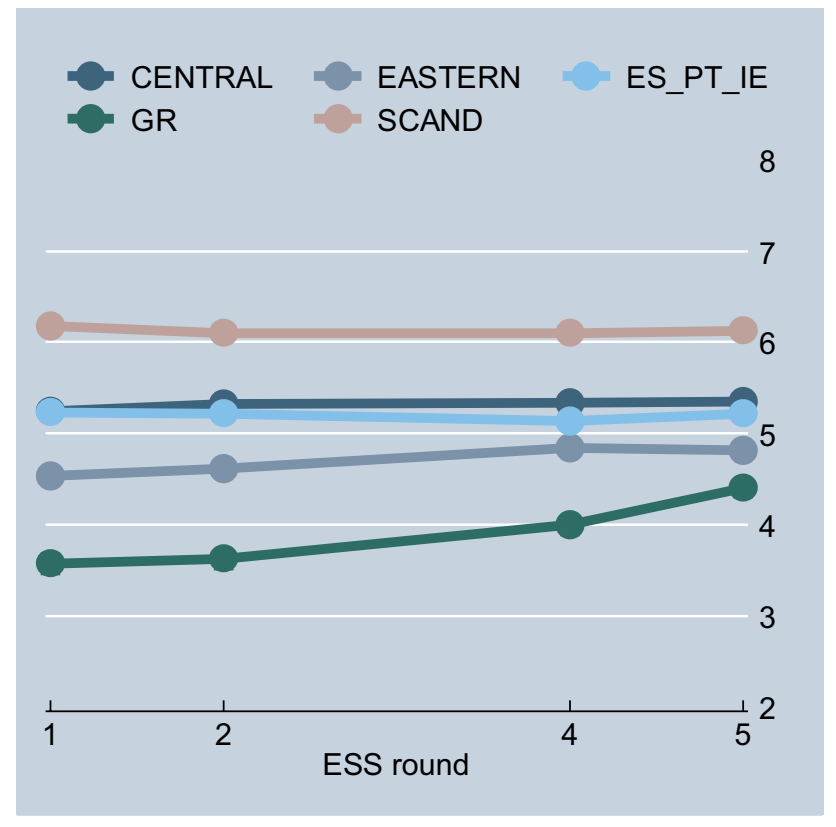

Fig. 4 Predictive margins for social trust: Greece versus aggregate groups of 17 European countries $($ CENTRAL $=$ Belgium, Switzerland, Germany, France, United Kingdom, and the Netherlands; EASTERN = Czech Republic, Hungary, Poland, and Slovenia; ES_PT_IE = Spain, Portugal, and Ireland; SCAND = Finland, Sweden, and Norway) 


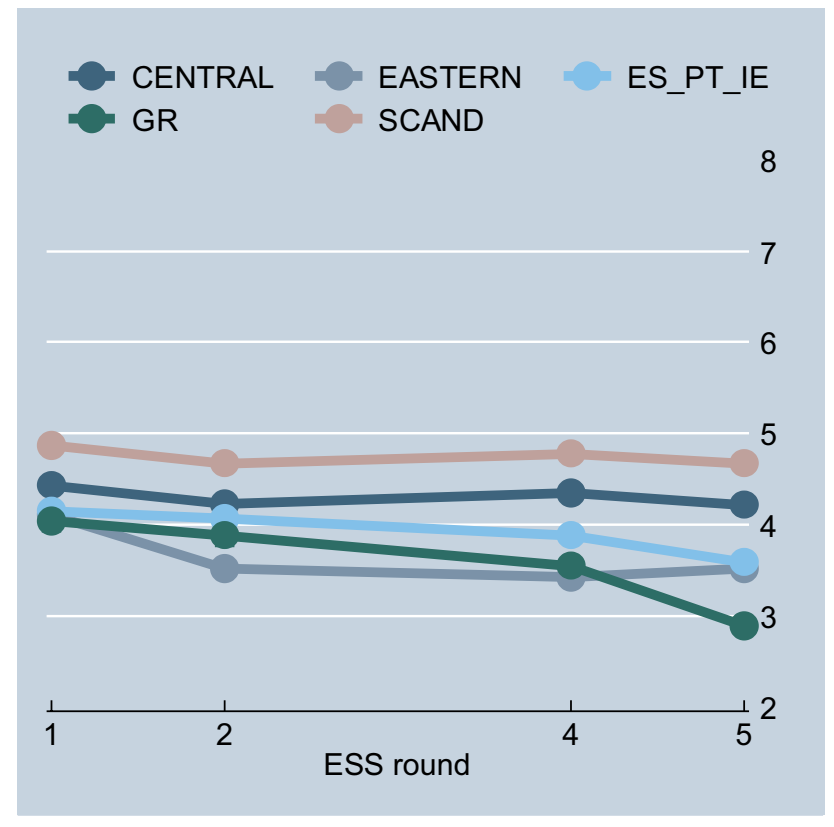

Fig. 5 Predictive margins for political trust: Greece versus aggregate groups of 17 European countries $($ CENTRAL $=$ Belgium, Switzerland, Germany, France, United Kingdom, and the Netherlands; EASTERN = Czech Republic, Hungary, Poland, and Slovenia; ES_PT_IE = Spain, Portugal, and Ireland; SCAND = Finland, Sweden, and Norway) 


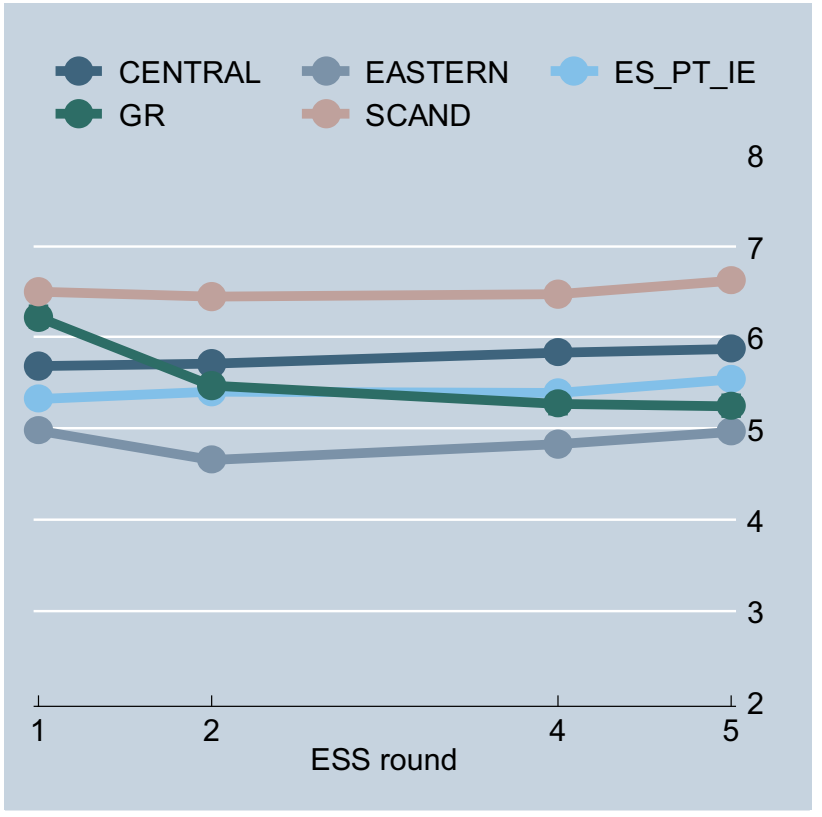

Fig. 6 Predictive margins for trust in impartial institutions: Greece versus aggregate groups of 17 European countries (CENTRAL = Belgium, Switzerland, Germany, France, United Kingdom, and the Netherlands; EASTERN = Czech Republic, Hungary, Poland, and Slovenia; ES_PT_IE = Spain, Portugal, and Ireland; SCAND = Finland, Sweden, and Norway)

\section{References}

Alesina, A., \& La Ferrara, E. (2000). The determinants of trust. National Bureau of Economic Research Working Paper 7621. http://www.nber.org/papers/w7621. Accessed May 12017.

Alesina, A., \& Wacziarg, R. (2000). The economics of civic trust. In S. J. Pharr \& R. D. Putnam (Eds.), Disaffected democracies: What's troubling the trilateral countries? (pp. 149-172). Princeton: Princeton University Press.

Almond, G., \& Verba, S. (1963). The civic culture. Princeton, NJ: Princeton University Press.

Anderson, J. E. (2015). The economic crisis and its impact on trust in institutions in transition countries. Unpublished manuscript. Available at SSRN: https://ssrn.com/abstract=2652265 or http://dx.doi. org/10.2139/ssrn.2652265. Accessed May 12017.

Arghyrou, M. G., \& Tsoukalas, J. D. (2011). The Greek debt crisis: Likely causes, mechanics and outcomes. The World Economy, 34(2), 173-191. https://doi.org/10.1111/j.1467-9701.2011.01328.x.

Braun, D., \& Tausendpfund, M. (2014). The impact of the Euro crisis on citizens' support for the European Union. Journal of European Integration, 36(3), 231-245.

Brehm, J., \& Rahn, W. (1997). Individual-level evidence for the causes and consequences of social capital. American Journal of Political Science, 41(3), 999-1023.

Christopherson, S., Clark, G. L., \& Whiteman, J. (2015). Introduction: The Euro crisis and the future of Europe. Journal of Economic Geography, 15, 843-853.

Dalton, R. (2004). Democratic challenges, democratic choices: The erosion of political support in advanced industrial democracies. Oxford: Oxford University Press.

De Grauwe, P. (2013). Design failures in the Eurozone: Can they be fixed? London School of Economics, 'Europe in Question' Discussion Paper Series. LEQS Paper No. 57/2013.

Delhey, J., \& Dragolov, G. (2013). Why inequality makes Europeans less happy: The role of distrust, status anxiety, and perceived conflict. European Sociological Review, 30(2), 151-165.

Delhey, J., \& Newton, K. (2003). Who trusts? The origins of social trust in seven societies. European Societies, 5(2), 93-137. 
Delhey, J., \& Newton, K. (2005). Predicting cross-national levels of social trust: Global pattern or Nordic exceptionalism? European Sociological Review, 21(4), 311-327.

Denters, B., Gabriel, O., \& Torcal, M. (2007). Political confidence in representative democracies: Sociocultural vs political explanations. In J. W. van Deth, J. R. Montero, \& A. Westholm (Eds.), Citizenship and involvement in European democracies: A comparative analysis (pp. 66-87). London: Routledge.

European Social Survey Round 1 Data. (2002). Data file edition 6.4. NSD-Norwegian Centre for Research Data, Norway-Data archive and distributor of ESS data for ESS ERIC.

European Social Survey Round 2 Data. (2004). Data file edition 3.4. NSD-Norwegian Centre for Research Data, Norway-Data archive and distributor of ESS data for ESS ERIC.

European Social Survey Round 4 Data. (2008). Data file edition 4.3. NSD-Norwegian Centre for Research Data, Norway-Data archive and distributor of ESS data for ESS ERIC.

European Social Survey Round 5 Data. (2010). Data file edition 3.2. NSD—Norwegian Centre for Research Data, Norway-Data archive and distributor of ESS data for ESS ERIC.

Exadaktylos, R., \& Zahariadis, N. (2012). Policy implementation and political trust: Greece in the age of Austerity. Hellenic Observatory Papers on Greece and Southern Europe, No. 65 December 2012.

Fukuyama, F. (2001). Social capital, civil society and development. Third World Quarterly, 22(1), 7-20.

Growiec, K., Vilhelmsdottir, S., \& Cairns, D. (2012). Social capital and the financial crisis: the case of Iceland. CIES e-Working Paper No. 138/2012.

Hardin, R. (1999). Do we want trust in government? In M. E. Warren (Ed.), Democracy and trust (pp. 22-41). Cambridge: Cambridge University Press.

Hardin, R. (2000). The public trust. In S. Pharr \& R. D. Putnam (Eds.), Disaffected democracies: What's troubling the trilateral countries? (pp. 31-51). Princeton: Princeton University Press.

Helliwell, J., Huang, H., \& Wang, S. (2014). Social capital and well-being in times of crisis. Journal of Happiness Studies, 15(1), 145-162.

Helliwell, J., \& Putnam, R. D. (1999). Education and social capital. NBER Working Paper, No. 7121.

Hooghe, M., \& Stolle, D. (2003). Introduction: generating social capital. In M. Hooghe, \& D. Stolle (Eds.), Generating social capital. Civil society and institutions in comparative perspective (pp. 1-18). New York: Palgrave MacMillan.

Ifanti, A. A., Argyriou, A. A., Dalofonou, F. H., \& Kalofonos, H. (2013). Financial crisis and austerity measures in Greece: Their impact on health promotion policies and public health care. Health Policy, 113(1-2), 8-12. https://doi.org/10.1016/j.healthpol.2013.05.017.

Jones, N., Chrisovaladis, M., Iosifides, T., \& Sophoulis, C. M. (2008). Social capital in Greece: Measurement and comparative perspectives. South European Society \& Politics, 13(2), 175-193.

Kääriäinen, J., \& Lehtonen, H. (2006). The variety of social capital in welfare state regimes: A comparative study of 21 countries. European Societies, 8(1), 27-57.

Karanikolos, M., Mladovsky, P., Cylus, J., Thomson, S., Basdu, S., Stuckler, D., et al. (2013). Financial crisis, austerity, and health in Europe. The Lancet, 381, 1323-1331.

Kawachi, I., Subramanian, S. V., \& Kim, D. (Eds.). (2007). Social capital and health. New York: Springer.

Kentikelenis, A., Karanikolos, M., Reeves, A., McKee, M., \& Stuckler, D. (2014). Greece's health crisis: From austerity to denialism. The Lancet, 383(9918), 748-753.

Knack, S., \& Keefer, P. (1997). Does social capital have an economic payoff? Quarterly Journal of Economics, 112, 1251-1273.

Kouvo, A., Kankainen, T., \& Niemelä, M. (2012). Welfare benefits and generalized trust in Finland and Europe. In H. Ervasti, J. G. Andersen, T. Fridberg, \& K. Ringdal (Eds.), The future of the welfare state. Social policy attitudes and social capital in Europe (pp. 195-213). Cheltenham: Edward Elgar.

Kuhn, T., \& Stoeckel, F. (2014). When European integration becomes costly: The euro crisis and public support for European economic governance. Journal of European Public Policy, 21(4), 624-641. https ://doi.org/10.1080/13501763.2013.867892.

Kumlin, S., \& Rothstein, B. (2005). Making and breaking social capital. The impact of welfare-state institutions. Comparative Political Studies, 38(4), 339-365.

Levi, M. (1998). A state of trust. In V. Braithwaite \& M. Levi (Eds.), Trust and governance (pp. 77-101). New York: Russell Sage Foundation.

Marien, S., \& Hooghe, M. (2011). Does political trust matter? An empirical investigation into the relation between political trust and support for law compliance. European Journal of Political Research, 50, 267-291.

Matsaganis, M. (2012). Social policy in hard times: The case of Greece. Critical Social Policy, 32(3), 406-421.

Miller, A., \& Listhaug, O. (1999). Political performance and institutional trust. In P. Norris (Ed.), Critical citizens: Global support for democratic government (pp. 204-216). Oxford: Oxford University Press. 
Newton, K. (2007). Social and political trust. In R. J. Dalton \& H.-D. Klingemann (Eds.), The Oxford handbook of political behavior (pp. 342-361). Oxford: Oxford University Press.

Norris, P. (2011). Democratic deficit: Critical citizens revisited. Cambridge: Cambridge University Press.

Papadopoulos, T., \& Roumpakis, A. (2012). The Greek welfare state in the age of austerity: Anti-social policy and the politico-economic crisis. In M. Kilkey, G. Ramia, \& K. Farnsworth (Eds.), Social policy review 24: Analysis and debate in social policy (pp. 205-230). Bristol: Policy Press.

Paraskevopoulos, C. J. (2012). Corruption, Inequality and Trust: the Greek vicious circle from incremental adjustment to "critical juncture"? CES papers, Open Forum \# 13, Center for European Studies, Harvard University.

Polavieja, J. (2013). Economic crisis, political legitimacy, and social cohesion. In D. Gallie (Ed.), Economic crisis, quality of work and social integration: The European experience (pp. 256-278). Oxford: Oxford University Press.

Putnam, R. D. (2000). Bowling alone: The collapse and revival of American community. New York: Simon $\&$ Schuster.

Rabe-Hesketh, S., \& Skrondal, A. (2012). Multilevel and longitudinal modeling using Stata (3rd ed.). College Station, TX: STATA Press.

Rachiotis, G., Stuckler, D., McKee, M., \& Hadjichristodoulou, C. (2015). What has happened to suicides during the Greek economic crisis? Findings from an ecological study of suicides and their determinants (2003-2012). BMJ Open, 5(3), e007295. ISSN 2044-6055 https://doi.org/10.1136/bmjop en-2014-007295.

Rose, D., Harrison, E., \& Pevalin, D. (2010). The European socio-economic classification: A prolegomen. In D. Rose \& E. Harrison (Eds), Social class in Europe. An introduction to the European socio-economic classification (pp. 3-38). Oxon: Routledge.

Roth, F. (2009). The effect of the financial crisis on systemic trust. Intereconomics, 44(4), 203-208. https:// doi.org/10.1007/s10272-009-0296-9.

Roth, F., Nowak-Lehmann, F., \& Otter, T. (2011). Has the Financial crisis shattered citizens' trust in national and European governmental institutions? Centre for European Policy Studies (CEPS) Working Document, No. 343, June 2011 (update).

Rothstein, B. (2008). Is the universal welfare state a cause or an effect of social capital? QoG Working Paper Series 2008: 16.

Rothstein, B., \& Stolle, D. (2003). Social capital, impartiality and the welfare state: An institutional approach. In M. Hooghe, \& D. Stolle (Eds.), Generating social capital. Civil society and institutions in comparative perspective (pp. 191-209). New York: Palgrave MacMillan.

Schmidt-Catran, A. W., \& Fairbrother, M. (2016). The random effects in multilevel models: Getting them wrong and getting them right. European Sociological Review, 32(1), 23-38.

Simonazzi, A., Ginzburg, A., \& Nocella, G. (2013). Economic relations between Germany and southern Europe. Cambridge Journal of Economics, 37, 653-675.

Sotiropoulos, D. A., \& Bourikos, D. (2014). Economic crisis, social solidarity and the voluntary sector in Greece. Journal of Power, Politics \& Governance, 2(2), 33-53.

Torcal, M. (2014). The decline of political trust in Spain and Portugal: Economic performance or political responsiveness? American Behavioral Scientist, 58(12), 1542-1567.

Torcal, M. (2017). Political trust in Western and Southern Europe. In S. Zmerli \& T. W. G. van der Meer (Eds.), Handbook of social trust (pp. 418-439). Cheltenham: Edward Elgar.

Uslaner, E. M. (2000). Producing and consuming trust. Political Science Quarterly, 115, 569-590.

Uslaner, E. M. (2008). Trust as a moral value. In D. Castiglione, J. Van Deth, \& G. Wolleb (Eds.), Handbook of social capital (pp. 101-121). Oxford: Oxford University Press.

Uslaner, E. M. (2010). Trust and the economic crisis of 2008. Corporate Reputation Review, 13(2), $110-123$.

van der Cruijsen, C., de Haan, J., \& Jansen, D. J. (2016). Trust and financial crises experiences. Social Indicators Research, 127, 577-600.

van der Meer, T. (2010). In what we trust? A multi-level study into trust in parliament as an evaluation of state characteristics. International Review of Administrative Sciences, 76(3), 517-536.

van der Meer, T. (2017). Democratic input, macroeconomic output and political trust. In S. Zmerli \& T. W. G. van der Meer (Eds.), Handbook of social trust (pp. 270-284). Cheltenham: Edward Elgar.

van Oorschot, W., \& Arts, W. (2005). The social capital of European welfare states: the crowding out hypothesis revisited. Journal of European Social Policy, 15(1), 5-25.

Warren, M. E. (1999). Introduction. In M. E. Warren (Ed.), Democracy and trust (pp. 1-21). Cambridge: Cambridge University Press. 
Wrightsman, L. S. (1991). Interpersonal trust and attitudes toward human nature. In J. P. Robinson, P. R. Shaver, \& L. S. Wrightsman (Eds.), Measures of personality and social psychological attitudes (Vol. 1, pp. 373-412). San Diego: Academic Press.

Yamagishi, T. (2001). Trust as a form of social intelligence. In K. S. Cook (Ed.), Trust in society (Vol. 2, pp. 121-147). New York: Russell Sage Foundation.

Zmerli, S., \& Newton, K. (2013). Winners, losers and three types of trust. In S. Zmerli \& M. Hooghe (Eds.), Political trust: Why context matters (pp. 67-94). Colchester: ECPR Press.

Zmerli, S., Newton, K., \& Montero, J. R. (2007). Trust in people, confidence in political institutions, and satisfaction with democracy. In J. W. Van Deth, J. R. Montero, \& A. Westholm (Eds.), Citizenship and involvement in European democracies: A comparative analysis (pp. 35-65). Abingdon: Routledge. 